\title{
Innovations in agriculture and population growth in Friuli (north-eastern Italy, seventeenth century)
}

\author{
Alessio Fornasin \\ University of Udine, Department of Economics and Statistics
}

\section{Introduction}

More than two centuries after the publication of Thomas Malthus' Essay on the Principle of Population (1798), the debate about the relations between population and resources continues. According to Malthus, population grows as long as there are sufficient food resources for its livelihood. If the number of inhabitants in a given territory exceeds the land capacity to produce enough food for its maintenance, then repressive checks restore the equilibrium. This return to balance is achieved by famines, by epidemics, and by wars. Alternatively, populations may put in place preventive checks that leverage their ability to contain their growth by postponing the age at marriage, increasing celibacy, and abstaining from sexual relations.

In more recent times, Malthus' vision was overturned by Ester Boserup (1981). According to this scholar, a population increase would push innovations in agriculture that would allow an increasing number of people to be sustained by the same land surface. The conflict between the two perspectives, though it has generated a vast literature, is still unresolved, and there is no lack of attempts at conciliation ${ }^{\text {. }}$.

Even within the framework proposed by Malthus, technical advancements may occur that allow an increase in production. In this case, the population can grow to higher numbers, but always without exceeding the

1 I have given here a brief summary of much larger debates. For a broad overview see

Livi Bacci 2017. 
limits of land-carrying capacity. After a certain period, the pressure of the population on resources begins to make its effects felt again and, depending on the demographic behaviour adopted, a new, often unstable, balance is restored.

This paper proposes, within the framework outlined by Malthus, an empirical verification of population growth, determined by the increase in the carrying capacity of a territory. The paper explores this topic with reference to Friuli (north-eastern Italy) during the seventeenth century when maize cultivation began to spread.

The links between the spread of new crops and population dynamics have already been explored in the literature. It has, in fact, often been noted that where new crops can guarantee an increase in production, they stimulate population growth (Crosby 1972). Although this process has become common knowledge, there is little evidence of the causal relationship between the two factors.

Perhaps the most discussed example is potatoes and population growth in Ireland. The first studies date to the middle of the last century (Salaman 1949; Connell 1950). Malthusian assumptions about the relationship between these two elements have been critically reviewed, particularly in later works, but the pattern whereby the potato fuelled Irish population growth in the second half of the eighteenth century has been confirmed (Mokyr 1981). Recently, with reference to the whole of Europe, it has been estimated that the introduction of the potato increased the population of the continent by some $25 \%$ (Nunn and Qian 2011). There are also studies in this direction with regard to maize, though the diffusion of this cereal has been given an economic rather than a demographic reading. However, recently Chen and Kung (2016) studied the effect of the introduction of maize in China from the seventeenth to the twentieth century. They estimated a population increase of $19 \%$ between 1776 and 1910.

In Italy this topic was addressed by Giovanni Levi (1991). According to this author, "Technological evolution, particularly in agriculture, has not led, over the course of the three centuries from the sixteenth century to the end of the eighteenth century, to decisive turns of immediate effectiveness such as to allow production and the population to grow in a lasting and consistent manner. Only one innovation has had a truly revolutionary character: the spread of maize" (Levi 1991, 141). According to Levi, the introduction of maize allowed both a population increase and economic growth. However, the difficulty in identifying causal relationships has 
also raised doubts about the real role of maize in population dynamics: "Presently, lacking reliable evidence on rural diets before maize introduction, any conclusion about its function in eighteenth-century population growth is premature, not very useful, and perhaps even misleading" (Finzi and Baiada 1985, 335). The issue, in short, is still under discussion. Here I intend to propose a further element of reflection on this topic, introducing some new aspects regarding the use of sources, the territorial scale, the time scale, and the reference period. It should be noted that: 1) The studies on the topic usually concentrate on the macro-territorial level, and propose comparisons between different areas. In this work, instead, the scale is regional and comparisons are made between communities. The research hypothesis is that what is observed at a regional level should also be observed at a more circumscribed level. 2) The time scale is typically measured in centuries. In this case, however, the time span is only three decades. The hypothesis here is that population growth can be observed as soon as the availability of resources begins to increase. 3) The reference period is usually the eighteenth century, when continental population growth is unequivocal. In this paper, instead, the first half of the seventeenth century is studied. If the cause of population increase is to be attributed to the introduction of the new culture, then the growth would surely be seen from the moment in which the innovation had its effects in terms of food availability.

After the introduction, I divided the paper into six parts. In the first part, making use of the literature on the subject, I briefly retrace the way that maize spread in Italy. In the third paragraph I describe, from an economic and social point of view, the territorial context of the study and present the sources. In the next part I reconstruct the distribution of maize in Friuli in the middle of the seventeenth century. In paragraph five, I illustrate the connections between the use of maize and population growth. In paragraph six, I analyse the results, and offer conclusions in the last part.

\section{The spread of maize in northern and central Italy}

We do not know for sure when maize was first grown in Europe. We know, however, that it began to appear in sources in the early 1500 . For Italy, the way in which maize spread has been known roughly for many years, not least thanks to Antonio Messedaglia (1927). Over the years, the growth of 
maize research has better clarified its diffusion both regionally ${ }^{2}$ and nationally (Cazzola 1991; Finzi 2009; Mantelli 1998). The cereal was also introduced in Friuli in the late sixteenth and early seventeenth centuries ${ }^{3}$. The price lists of Udine, the reference market for the whole Friuli region, included maize for the first time already in 1622, but its presence is certified in notarial contracts only after 1630 (Fornasin 1999).

At first, maize was considered a curiosity and its cultivation was limited to botanical gardens; then in later stages it spread to the countryside. It requires large quantities of water for its cultivation, so it is believed that it first spread on wetlands, where there were also higher yields. Afterward, it gained more and more space on dry soils, where, although the yields were much lower, its greater resistance compared to other cereals was useful. Maize competed with other spring cereals. In Piedmont, the initial success of the new crop was limited to areas where sorghum was preferred (Levi 1979, 1094). In Lombardy, the introduction of maize did not alter traditional rotation systems, but was limited only to replacing spring cereals (Coppola 1979). Finally, the same propagation models were observed for Emilia and Romagna (Poni 1963, 48; Cazzola 1991, 115-117; Bolognesi 1986, 167), and for Tuscany, where the spread of maize mainly replaced legumes (Mineccia 1983, 327). The new crop competed with other cereals that had a similar growing season. For this reason, therefore, its diffusion had only a limited influence on the cultivation of wheat and rye which, in Italy, were sown in autumn and harvested in June ${ }^{4}$.

The spread of the American cereal in the countryside did not automatically mean that it was used for food. This question is fundamental for the present study, as we cannot speak of connections between this crop and population growth unless the stages of its consumption are outlined first. In Friuli, as in other areas of central and northern Italy, the peasant family, who worked on the farms of large landowners, used winter cereals, in particular wheat, for the payment of rents and as exchange goods. The rural population was mainly fed with spring cereals, while the urban population typically ate winter cereals. From this point of view, therefore, the spread of maize should represent a good approximation to the consumption of this cereal in the countryside. According to numerous studies, mistrust had

$2 \quad$ Piedmont, Levi 1979; Lombardy, Coppola 1979; Venetian, Fassina 1982, Gasparini 2002; Emilia, Finzi, Baiada 1985; Romagna, Bolognesi 1986; in comparative form, Mocarelli and Vaquero Piñeiro 2018.

3 The first attestation, however, dates back to 1600 (Morassi 1997, 184).

4 Regarding the agricultural calendar in Italy, I point out Istat 1937. 
hindered the consumption of maize among rural populations (Levi 1979). There was also the fact that, at least according to Roberto Finzi (2009), it provided little energy, and after consuming it the satiety effect was short lived. In any case, these reserves were eventually overcome when maize presented itself as an alternative to hunger. As illustrated by Giovanni Levi, in relation to northern Italy, it became an important part of the peasant diet only after the great plague of 1630 . But there is evidence that already during the crises of the second half of the sixteenth century it substituted the traditional food of the peasants (Cazzola 1991).

In Friuli, as in other areas of northern Italy, there was initial resistance to its consumption. Then, from the famine of 1629 onward, maize, in the form of polenta, began to spread on the peasants' tables, until it became, in the late nineteenth century, the dominant, and in many cases exclusive, food of a large part of the population (Fornasin 1999; Bof 2005). This spread had, as we know, significant consequences, not least in terms of health. Maize is heavily vitamin deficient, as it is low in niacin. Therefore, a diet based exclusively or almost exclusively on this cereal could lead to pellagra. This disease, though, is only observed frequently in Friuli and northern Italy during the nineteenth century, and therefore far from the period we are dealing with, when the diet of the rural poor was evidently more varied (De Bernardi 1984; Livi Bacci 1986; Robiony 2003).

Despite initial difficulties, maize eventually became an important part of the diet. The new cereal was not only an efficient way to overcome crises. It was also the most advantageous crop, at least from the point of view of the grower/consumer, compared to the traditional spring cereals common in Friuli, such as red sorghum, buckwheat and millet. Although its nutritional value is close to other cereals that were cultivated in Friuli at the times, maize enjoyed other advantages over competing crops, in particular in terms of the yield ratio per unit area of land, and of the seed/crop ratio. Renzo Corritore estimated that, at the end of the eighteenth century, in some areas of the Po Valley the quintals/hectare ratio was 7.6 for maize, 5.1 for wheat, or 3.3 for other crops. The seed/crop ratio was 36.5 for maize, 4.1

5 In the tables of CREA (Consiglio per la ricerca in agricoltura e l'analisi dell'economia agraria) we see that there are no significant differences between cereals. They range from $1376 \mathrm{~kJ}$ of buckwheat to $1492 \mathrm{~kJ}$ of maize (red sorghum is not included in this database). Website: https://www.crea.gov.it/web/alimenti-e-nutrizione, accessed on 10 February 2020. Of course, varieties grown in the past could have given different results. For example, according to Malanima $(1998,163)$, the energy yield of wheat equalled 100, while that of maize equalled 162 . 
for wheat, and even lower for other crops (Corritore 2000, 41). The figures presented by Paolo Malanima for eighteenth-century Lombardy are different, but take us in the same direction: a hectare of land provided on average about $7.7 \mathrm{q}$ of wheat, and $12.9 \mathrm{q}$ of maize (Malanima 1998, 163).

\section{Context and sources}

The territory studied in this paper is the Patria del Friuli, the eastern part of the Venetian mainland. Friuli was economically backward compared to most of the kingdom's provinces. On the plains, the economy was based on agriculture, while in the mountains there were lively economic activities based mainly on the itinerant trade and some craft activities, but in the context of multi-activities (Morassi 1997; Bianco 1994; Fornasin and Lorenzini 2017). Craft activities were concentrated in urban areas.

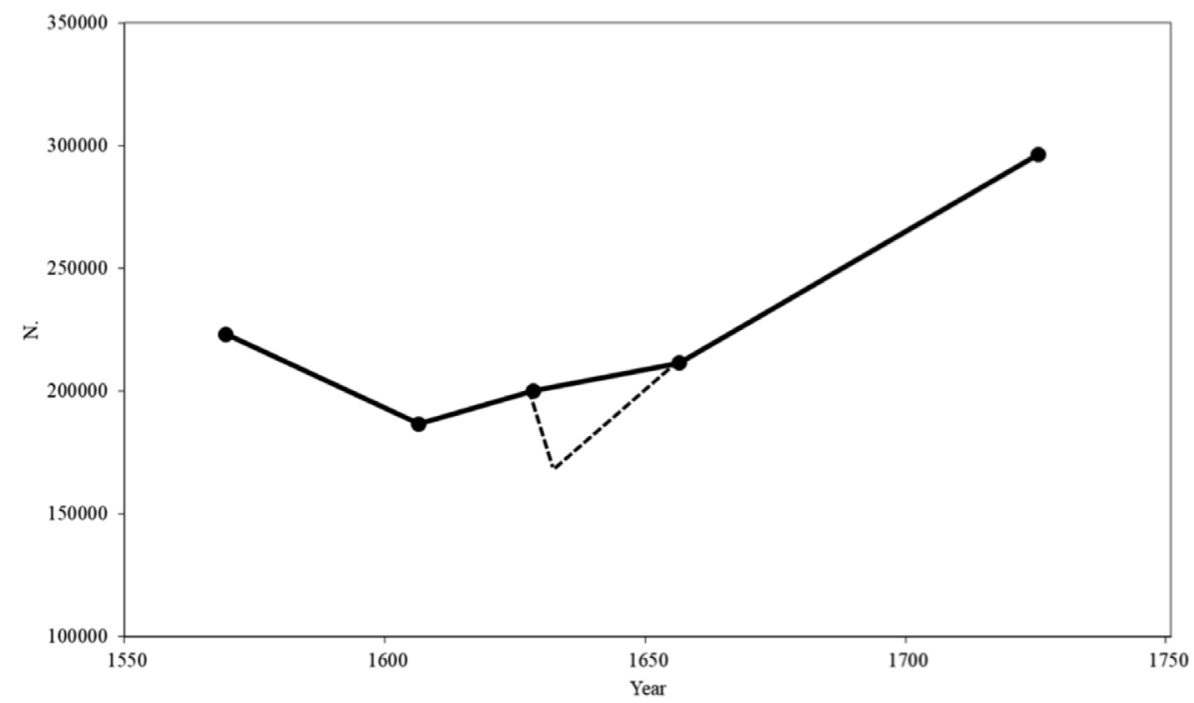

\section{Graph ı. Population of Friuli (1566-1725)}

From the demographic point of view, Friuli was a sparsely populated area compared to the rest of the mainland states (Zannini and Fornasin 1999). According to the most recent studies (Fornasin 2001; Fornasin and Lorenzini 2016), there were about 225,000 inhabitants in the second half of the sixteenth century (Graph 1). At the end of the century, the population had decreased significantly. The causes of this decline are to be found in the plague of 1575-76, and in other mortality crises at the end of the sixteenth 
century, but it is difficult to think only of short-term causes. After reaching one of its lows, the population began to rise. In 1606, there were fewer than 190,000 inhabitants; in 1628, about 200,000. The following year, the territory faced the greatest early-modern demographic crisis. Contrary to what had occurred in much of northern Italy, the crisis was not brought about by the plague, which only marginally affected Friuli in 1630, but by a terrible famine that plagued the territory in 1629. We do not know the quantitative outcome of the mortality crisis of that year, although it could have caused a decrease of about $20 \%$ of the population.

Many poor people, driven from the countryside, sought refuge and salvation in urban centres, e.g. in Udine, the capital of Friuli, and also in Venice. According to the Venetian chronicles of the time, 1629 was long remembered as "the year of the Friulians" (Ulvioni 1989, 39). Although we do not know how serious the decline in the population was from the year before the crisis to 1656 , the population there reached only 210,00o inhabitants. From 1656 to 1725 we observe a further increase which saw the population reach 300,000 by the end of the period.

The period investigated in this paper belongs to the phase of population growth that extends from the crisis of 1629 to the mid-seventeenth century. The analysis is based on two documents, one drawn up at the end of 1629 or at the beginning of 1630, and the other in 1656. Like all the censuses carried out by the Republic until the second half of the eighteenth century, the territorial unit of reference for the collection of information was the community, and the trackers were the village heads (Fornasin and Veronese 1999; Fornasin 2001; Fornasin and Lorenzini 2019).

The first survey considered was directly promoted by the Venetian government following the crisis of 1629. The authorities wanted to know the quantitative results of the famine to predict with reasonable approximation what might happen in the near future, in particular with regard to population flows. As I have already noted, the crisis led to a very strong rise in mortality, but it also gave rise to important migration towards certain urban centres, in particular Venice. It was, therefore, important to understand what the consequences would be for the consumption of cereals in the city. One of the objectives, therefore, was to establish what quantities of grains Venice should bring together from the other provinces of the domain to deal with the emergency. The census results consisted of a list of 628 villages, for each of which the inhabitants are divided between home$n i$, done and putti (men, women and children). Then there are two further 
pieces of information: the number of deaths and the number of assenti, people who had temporarily emigrated to escape the crisis. Although the results of the census provide an important body of information, the territorial coverage was only partial. In fact, we estimate that several hundred villages are missing. In addition, the numbers of the deceased and absent were omitted for some centres. Some locations are repeated more than once and there are several other inaccuracies. Despite its shortcomings, however, the document is the most complete survey that has been passed down to us regarding the population of seventeenth-century Friuli.

The second census, called the Grimani Survey, the name of the Venetian governor in Friuli, was promoted by the central authorities in 1656. The War of Candia had been fought for more than ten years and the Republic was constantly looking for resources to continue the struggle. In this context, it decided to carry out a survey relating to Friuli to assess whether there was the possibility of extracting grains for the supply of the fleet. The survey has reached us largely incomplete and concerns 137 villages scattered throughout the country. To determine how much grain to extract, however, it was necessary to establish what the province's needs were. For this reason, the survey has two parts ${ }^{6}$. In the first one, all the households of individual communities are listed, often including the number of males, females and putti, and in some cases the names of individual family members. In the second part, information is provided on the stocks of cereals and legumes kept by the households in their granaries. In this regard, two clarifications must be made: 1) The investigation took place in November, therefore a short time after the harvest of the spring cereals, when only a small part of these cereals had been consumed, while more than five months had passed from the harvest of the winter cereals. 2) Spring cereals, since they were the basis of the rural classes' diets, were kept in private homes, while winter cereals were largely transferred to the manor houses, to monasteries, and to the public granaries of urban centres. The 1656 survey is an important and, in some ways, unique document, because it allows us to connect the demographic and the economic characteristics of a considerable number of villages. Used jointly with the survey of 1629 , it also allows us to study the evolution of the population of the Patria del Friuli, taking into consideration the different diffusion of maize in the territory at the end of the period.

6 The source was used partly in Pietra (1944) and in Fornasin (1999). 


\section{Maize in Friuli in the mid-seventeenth century}

Before moving on to an analysis based on the information contained in the 1656 document, I am able to draw the distribution and diffusion of maize in the territory concerned in the survey. For this operation I do not use absolute data, but rather the percentage quantities at village level. That is to say, the percentage of maize compared to the total of cereals with the same sowing and harvesting period. The results of this processing are summarized in Map 1. The map gives an account of the territorial distribution of the centres involved in the survey and also of the distribution of maize. The size of the circles is in direct proportion to its percentage.

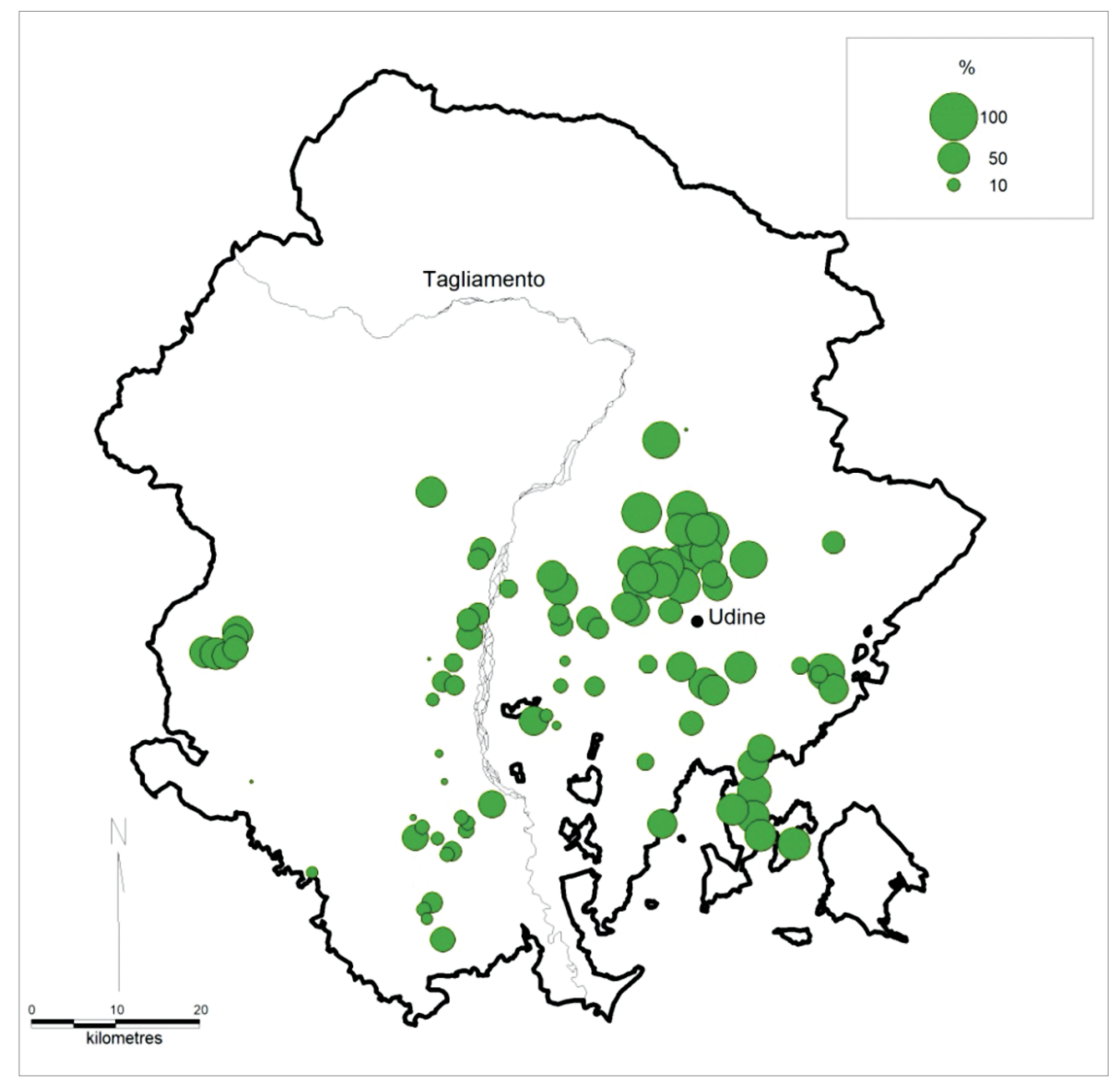

Map i. Maize percentage in total spring cereals. Friuli 1656 
Although the survey is incomplete in terms of territorial coverage, the map allows us to identify quite clearly the areas where maize was most widespread. The geography thus outlined also shows us the spread of the new cereal a few decades after the start of its use as a food.

In the lower eastern Friuli region, all the villages involved in the survey were rich in maize. This situation seems to be the same towards the north, in the villages near Udine. Here the diffusion area opens, and involves a wide range of locations north of the city. The substantial number of observations relating to this area assigns, without exception, high percentages of maize. It can be concluded that this was the Friulian area most suited to the cultivation of maize. To the west of the Tagliamento River, the new crop was an important reality in some villages of the western foothills, perhaps for the same reasons it was widely cultivated in the nearby Belluno area (Fassina 1982, 47-50). In the rest of the Patria, with a few notable exceptions, maize was present to a lesser extent or was completely absent. To the east of the north-south axis that passed roughly through Udine, maize was, in the areas covered by the Grimani Survey, completely absent in the eastern mountain district. In these territories, wheat, rye or even oats were alternated in crop rotations with red sorghum and buckwheat. To the west of this same axis, maize is attested in much smaller quantities than the average, both in the low and the medium plains. Similar results have been obtained by analysing the plain to the east of the Tagliamento River, where the cereal was used least. A different situation applies to the more northern territories. The location of maize in seventeenth-century Friuli, as it emerges from the Grimani Survey, is in some ways surprising. To date, it has been frequently suggested that maize cultivation began in the marshy areas of the Veneto countryside. These data suggest, however, that an early start was not followed by an equally early affirmation. In 1656, a good part of the lower plain was still poor in terms of maize. Most of the American cereal was found in its eastern part, while in the western part it was only found in the foothills. There is absolutely no information on the northern part of the province, but since it is an Alpine area, the relevant territory imported most of the cereals from the outside. This distribution of maize only partially follows the physical and climatic subdivisions of the province, and seems rather the result of other processes which, at the moment, I am not able to identify. One hundred and fifty years later, things were very different. According to a nineteenth-century survey, maize was widespread with percentages close to $90 \%$ across the region. 
On the basis of the information contained in the surveys of 1629 and 1656 , I am able to study the evolution of the population of 116 villages, which rose from 26,649 inhabitants to 28,760 . Considering that the most terrible famine in the history of Friuli had occurred close to the first date, there is no doubt that the population was resilient. However, although the population had grown between 1629 and 1656, there were different trends in different communities. In 38 villages the population, in fact, decreased. It is possible, of course, that some of the results are incorrect, but the general trend that emerges from the available information cannot be subverted.

\section{Maize and population growth}

In this part of the paper I use data on population and on the availability of cereals to build a statistical model that allows us to see if the spread of maize determined the population growth of Friuli in the first half of the seventeenth century. The model is a multiple regression in which the dependent variable, or the characteristic that is explained by the other variables, is population growth between 1628 and 1656 .

With this model I am not proposing a simple association between the presence of maize and population growth, but I introduce other variables that can help to explain its increase. The first, and the main one, concerns the diffusion of maize in individual villages, recognized as the percentage of the quantity of maize stored in the granaries of a village and the total amount of spring cereals. The second variable concerns the availability in absolute terms of spring cereals and legumes at the village level. This information was introduced as the quantities of per capita consumer products, limited to those used by rural populations, without considering wheat and rye, which may also influence population growth. The assumption is that there is a direct relationship between the availability of consumer goods and the population. It must also be said that, due to the survey methods, I suspect there is a serious bias in this information. The census trackers, who, as we have seen, were the heads of village councils, had every interest in underestimating the quantities of cereals. This underestimation, which we can consider systematic, certainly varied from subject to subject. On the contrary, I think that, if only to preserve a certain consistency in the data, these same officers were more careful to ensure a balance in the proportions of the different cereals, which is the method used in this paper to reconstruct the spread of maize across the territory. The third variable is the average number of members per household at the village level. The basic as- 
sumption is that in a period of population growth, families tend to be larger than in phases of decline. This effect may be due to an increase in fertility, i.e. more children per household, but also to a decline in mortality, i.e. more members per household distributed in other age groups. The fourth and last variable is the percentage of deaths and emigrants out of the total population of 1628. It has already been said that these data are incomplete, but I wanted to take into account, at least partially, the effects of the 1629 crisis on the population. The hypothesis is that the more consistent the loss of population during the crisis, the smaller the population growth recorded between the pre-famine data and 1656 . The results of the model are shown in Table 1.

\section{Table r. Determinants of the increase of population in Friuli (1628-1656)}

\begin{tabular}{lcc} 
& Coef. & $\mathrm{P}>\mathrm{t}$ \\
Maize/other cereals & 0.212 & 0.005 \\
\hline Kg of cereals per inhabitant & -0.062 & 0.118 \\
\hline No. of family members & 0.088 & 0.006 \\
\hline$\%$ of deaths and emigrants between 1628 and 1629 & -0.008 & 0.045 \\
\hline & & \\
\hline Number of obs & 116 & \\
\hline F $(4,111)$ & 4.30 & \\
\hline Prob $>$ F & 0.003 & \\
\hline Adj R-squared & 0.10 & \\
\hline
\end{tabular}

To make the table easier to read, I would like to state that the sign of the coefficient (second column) indicates whether the relationship between the variable considered is direct (positive value) or inverse (negative value) with respect to population growth, while the higher its value, the greater its influence. The third column of the table indicates whether these values are statistically significant. Following a consolidated practice in the social sciences, values lower than 0.05 are considered significant. Below this threshold, the smaller the data shown, the more certain the result achieved. Having said this, when we look at the results of the model, we can see that the share of maize among other cereals is positively correlated with population growth. In communities where there was more maize, therefore, the population grew a little faster. On the contrary, the amount of cereals available per capita is not a significant data. This aspect was expected and it is consistent with the starting hypothesis that the source is not reliable be- 
cause it specifies the absolute quantities of goods, but because it indicates to us, according to the modalities previously described, the different diffusion of maize. The average number of members per household is positively correlated with population growth and is also statistically significant. This result seems to me to be particularly important because, as we shall see in the next section, it helps to explain through which mechanisms population growth may have occurred. Finally, the effects of the famine of 1629 had a depressive effect on growth, since, in the face of greater losses in terms of deaths and emigrations, it was more difficult to return to the number of inhabitants before the crisis. This means that the villages that had been most affected by the crisis grew more slowly than the others. However, the relationship is weak, and the level of significance is also close to the limit.

\section{Discussion}

In seventeenth-century Friuli, there was a relationship between maize diffusion and population increase. However, there are at least two fundamental interpretative aspects that the model cannot resolve because there are several possible data readings. 1) It does not solve the basic dilemma: was it maize that determined population growth or, on the contrary, was it the demographic increase that stimulated the spread of maize? 2) It does not explain the mechanisms through which the cause-effect relationship between these two variables has been achieved.

With regard to the first point, the Malthusian rather than the Boserupian perspective seems to me much more plausible. This belief is not based on the way maize spread through the territory, which could also be consistent with the second perspective. It is based, instead, on the dynamics related to its consumption. As we have seen, the consumption of maize in Friuli, as in other territories, began to take hold in order to alleviate situations that had arisen following Malthusian crises: famines and epidemics. The introduction and, above all, the beginning of maize consumption took place, as I have already pointed out, in the context of a supply and not a demand crisis. In the Boserupian scheme, population growth is the driving force behind innovation in agriculture, but this does not seem to me to be the case in seventeenth-century Friuli. With regard to the second question, from a theoretical point of view, i.e. relating only to demographic accounting aspects, population growth may have manifested itself through one of these three factors or through a combination of the three: 1) increase in fertility; 2) decline in mortality; 3) positive net migration. 
Unfortunately, the sources used in this work do not allow for a clarification of these points. Both surveys report some overly approximate information on the structure of the population, which, in principle, could be used to estimate fertility and mortality. The survey of 1656, though it allows us to distinguish in many cases between adults and putti, is not detailed enough to resolve the issue. The age limit between these two components of the population is not fixed with precision and, much more serious for any analysis, it differs from village to village depending on who carried out the survey. An opportunity for further study is given by the collection and processing of data, which we can draw from the records of baptisms and burials kept in the parish archives. But precisely for this period, and partly due to the serious upheavals caused by the famine, the parish registers are very patchy. The possibility of collecting information on migratory flows, the quantification of which depends on parish registers, remains very problematic.

It is currently impossible, without information that allows a quantitative analysis, to reconstruct the mechanisms that may have come into action to trigger this growth. However, it seems to me that the same explanation that has been used to justify the growth of the Irish population after the introduction of the potato (Connell 1950) can be temporarily adopted for Friuli. In fact, this hypothesis is consistent with the data available and, also, with the results of the model. As we have seen, in the communities where we have observed greater population growth, there is also a greater increase in the average size of households. This effect may, of course, be due to two very different factors: 1) the increase in fertility, which translates into a higher number of children within the family, and therefore into an enlargement of the base of the population pyramid; 2) the increase in survival. In this case, since mortality was concentrated mainly among babies, we should see the growth of younger family members. On the other hand, infant mortality is not in direct correspondence with the consumption of maize, which concerns, mainly, the ages following weaning. If it is a consequence of increased survival, we should also see, in the data, its effects on the adult and elderly population. We have no other element to justify the growth of the population except a greater availability of food, which occurs, among other things, when there is no population pressure on the resources ${ }^{7}$. To reach a provisional conclusion,

7 Greater availability of food can also lead to an increase in mortality which can be balanced by greater fertility (Livi-Bacci 2017). 
it is more plausible to think of an increase in fertility. It remains to be seen how this could have happened. On the other hand, a phenomenon already invoked in the Irish context may have occurred, i.e. an advance in the age at marriage and/or a decrease in celibacy. Although I personally favour this hypothesis, it must be recognized that even this element is very difficult to verify empirically, since the relevant sources are the parish registers. In addition to the difficulties already mentioned, we must also add the fact that in the marriage registers of this period, the age of the spouses is not normally reported. This can be calculated only by linking together information from different registers.

\section{Conclusion}

In the context of seventeenth-century Friuli, and in particular after the great subsistence crisis of 1629 , the consumption of maize became more widespread. Not all of Friuli was interested in this phenomenon in the same way. By linking two different datasets built at the village level, it was possible to demonstrate that the spread of the new crop directly affected population growth and that this growth was more sustained in those territories that had adopted it earlier. The causal relationship between the spread of maize and population increase, and the mechanisms that underlie this growth, are not yet clear. However, the evidence emerging from this study is consistent with an interpretation that has also been used in other circumstances to explain the mechanisms of population growth. With the introduction of maize and its spread, more resources became available for the general population and for families. Thanks to this improved situation, the balance between population and resources became looser and, therefore, the preventive behaviours that populations had adopted to contain fertility also slackened. In this context, there may have been a reduction in the age at marriage and also a reduction in celibacy. In populations with natural fertility, the growth of nuptiality also led to an increase in fertility, which is the factor that directly determines population growth. It cannot be excluded, however, that the decrease in mortality, that of children in particular, played a role in demographic dynamics. Although the mechanisms of growth in the Friulian population of the seventeenth century cannot be fully clarified, at least at this stage, the link between innovation in agriculture and demographic development is reflected in this analysis. This connection seems to work in Malthusian terms: the introduction of maize stimulated population growth and not vice versa. 
Bibliography

Bianco, F. 1994. Le terre del Friuli. Mantova: Astrea. Verona: Cierre.

Bof, F. 2005. 'Per la storia dell'alimentazione in Friuli: fonti, studi, temi di ricerca (secoli XVII-XVIII).' Storia economica, 8 (2): 181-214.

Bolognesi, D. 1986. 'Una «regione» divisa. Economia e società in Romagna alla fine del Settecento.' In Spazi ed economie. L'assetto economico di due territori della padania inferiore, edited by F. Giusberti and A. Guenzi. 137271, Bologna: Il Mulino.

Boserup, E. 1981. Population and technological change: a study of long-term trends. Chicago: University of Chicago Press.

Cazzola, F. 1991. 'L'introduzione del mais in Italia e la sua utilizzazione alimentare (sec. XVI-XVIII).' Pact 26 (8): 109-127.

Connell, K. H. 1950. The Population of Ireland (1750-1845). Oxford: Clarendon Press.

Coppola, G. 1979. Il mais e l'economia agricola lombarda. Bologna: Il Mulino.

Corritore, R. P. 200o. La naturale "abbondanza" del Mantovano. Produzione, mercato e consumi granari a Mantova in età moderna. Pavia: Università di Pavia.

Crosby, A. 1972. Columbian Exchange: Biological and Cultural Consequences of 1492. Westport: Greenwood Press.

De Bernardi, A. 1984. Il mal della rosa. Denutrizione e pellagra nelle campagne italiane tra '8oo e '9oo, Milano: Angeli.

Fassina, M. 1982. 'L'introduzione della coltura del mais nelle campagne venete.' Società e storia 15: 31-59.

Finzi, R. 2009. Sazia assai ma dà poco fiato. Il mais nell'economia e nella vita rurale italiane, secoli XVI-XX, Bologna: CLUEB.

Finzi R., and E. Baiada. 1985. 'L'affermazione del mais nelle campagne bolognesi: un mutamento del regime alimentare?' In Popolazione ed economia dei territori bolognesi durante il Settecento, Bologna: Istituto per la storia di Bologna, 279-336.

Fornasin, A. 1999. 'Diffusione del mais e alimentazione nelle campagne friulane del Seicento.' In Vivere in Friuli. Saggi di demografia storica (secc. XVI-XIX), edited by M. Breschi, 21-42. Udine: Forum.

Fornasin, A. 2001. 'La popolazione del Friuli in età moderna. Conferme e nuove evidenze.' Memorie Storiche Forogiuliesi 81: 207-238. 
Fornasin A., and C. Lorenzini. 2016. 'La popolazione del Friuli veneto tra Quattro e Cinquecento.' In La popolazione italiana del Quattrocento e Cinquecento, edited by G. Alfani, A. Carbone, B. del Bo and R. Rao, 4155. Udine: Forum.

Fornasin A., and C. Lorenzini. 2017. 'Integrated Peasant Economy in Friuli (16th-18th Centuries).' In Integrated Peasant Economy in a Comparative Perspective. Alps, Scandinavia and Beyond, edited by A. Panjek, J. Larsson, and L. Mocarelli, 95-116. Koper: University of Primorska Press.

Fornasin A., and C. Lorenzini. 2019. 'La famiglia in Friuli fra XV e XVII secolo: fonti, problemi, prospettive.' In La famiglia tra mutamenti demografici e sociali, edited by F. Scalone and A. Samoggia, 85-96. Udine: Forum.

Fornasin, A., and G. Veronese. 1999. 'Fonti di stato per la ricostruzione della popolazione del Friuli dal 1548 alla caduta della Repubblica di Venezia.' In Vivere in Friuli. Saggi di demografia storica (secc. XVI-XIX), edited by M. Breschi, 243-52. Udine: Forum.

Gasparini, D. 2002. Polenta e formenton. Il mais nelle campagne venete tra XVI e XX secolo. Verona: Cierre.

Istat, 1937. Periodi di semina e di raccolto per le principali coltivazioni. Rome: Istat.

Levi, G. 1979. 'Innovazione tecnica e resistenza contadina: il mais nel Piemonte del '6oo.' Quaderni storici, 42: 1092-100.

Levi, G. 1991. 'L'energia disponibile.' In Storia dell'economia italiana. Vol. II. L'età moderna verso la crisi, 141-168. Torino: Einaudi.

Livi-Bacci, M. 1986. 'Fertility, Nutrition and Pellagra: Italy during the Vital Revolution.' Journal of Interdisciplinary History 16 (3): 431-454.

Livi-Bacci, M. 2017. A concise History of World Population. $6^{\text {th }}$ ed. London: Blackwell.

Malanima, P. 1998. La fine del primato. Crisi e riconversione nell'Italia del Seicento, Milan: Bruno Mondadori.

Malthus, T. R. 1798. An essay on the principle of population as it affects the future improvement of society, London: J. Johnson.

Mantelli, R. 'L'epoca della diffusione del mais. La maiscoltura nell'evoluzione economica dell'Italia (fine XVI secolo-fine XIX secolo).' In Prodotti e tecniche d'oltremare nelle economie europee. Secoli XIII-XVIII, edited by S. Cavaciocchi, 451-65. Firenze: Le Monnier.

Messedaglia, L. 1927. Il mais e la vita rurale in Italia. Saggio di storia agraria. Piacenza: Federazione italiana dei consorzi agrari. 
Mineccia, F. 1983. 'Note sulle fattorie granducali del pisano occidentale nell'età moderna: Antignano, Casabianca, Collesalvetti, Nugola, S. Regolo e Vecchiano.' In Agricoltura e aziende agrarie nell'Italia centrosettentrionale (secoli XVI-XIX), edited by G. Coppola, 286-341. Milano: Angeli.

Mocarelli, L., and M. Vaquero Piñeiro. 2018. 'El maíz en Italia, siglos XVI-XIX: precios, mercados y haciendas agrícolas (dos casos de estudio: Lombardía y Umbría).' Obradoiro de Historia Moderna, 27: 21-48.

Mokyr, J. 1981. 'Irish History with the Potato.' Irish Economic and Social History 8: 8-29.

Morassi, L. 1997. 1420-1797. Economia e società in Friuli. Udine: Casamassima.

Nunn, N., and N. Qian. 2011. 'The Potato's Contribution to Population and Urbanization: Evidence from a Historical Experiment.' The Quarterly Journal of Economics 126: 593-650.

Pietra, G. 1944. 'Di un frammento di censimento friulano del XVII secolo.' Statistica 4 (2): 105-115.

Poni, C. 1963. Gli aratri e l'economia agraria nel Bolognese dal XVII al XIX secolo. Bologna: Zanichelli.

Robiony, M. 2003. 'L'inchiesta sulla pellagra in Friuli a metà Ottocento.' Storia economica 6 (2): 287-314.

Salaman, R. N. 1949. The History and Social Influence of the Potato. Cambridge: Cambridge University Press.

Ulvioni, P. 1989. Il gran castigo di Dio. Carestia ed epidemie a Venezia e nella Terraferma. 1628-1632. Milan: Angeli.

Zannini, A., and A. Fornasin. 1999. 'Crisi e ricostruzione demografica nel Seicento veneto.' In La popolazione italiana nel Seicento, 103-122. Bologna: Clueb. 